\title{
Need to estimate the net global warming potential of nitrogenous fertilizers
}

\section{Opinion}

In several developing countries, including India, the production of food grain is mainly dependent on the use of fertilizers, particularly nitrogenous fertilizers which increases by many folds after industrialization and its use will further increase in future to meet the demand of increase food production. Use of fertilizer alters the global nitrogen $(\mathrm{N})$ cycle resulting to decline in total factor productivity and decreased nitrogen use efficiency (NUE). The N cycle is the conversion or transformation of molecular nitrogen $\left(\mathrm{N}_{2}\right)$ to other reactive forms and back to its original state. The $\mathrm{N}$ cycle is completed in five different steps namely, nitrogen fixation, nitrification, assimilation, ammonification and denitrification. ${ }^{1}$ During the nitrogen cycle many oxidised compounds i.e. nitrous oxide $\left(\mathrm{N}_{2} \mathrm{O}\right)$, oxides of nitrogen $\left(\mathrm{NO}_{\mathrm{x}}\right)$, and nitrate $\left(\mathrm{NO}_{3}-\right)$ and reduced compound i.e. ammonia $\left(\mathrm{NH}_{3}\right)$ are emitted into the atmosphere affecting the overall climate system. ${ }^{2}$ Being a potent green house gas $\mathrm{N}_{2} \mathrm{O}$ is directly contributed to global warming and its concern is greater than the $\mathrm{NH}_{3}, \mathrm{NO}_{x}$ and $\mathrm{NO}_{3}$ - nitrate due to its higher global warming potential (GWP) i.e., 310 times of $\mathrm{CO}_{2},{ }^{3}$ high global temperature change potential (GTP) i.e. 290 on 100year time scale ${ }^{4}$ and longer atmospheric life time i.e. about 116 years. In India agriculture is the major contributor with $70 \%$ of total $\mathrm{N}_{2} \mathrm{O}$ emission and $\mathrm{N}$ fertilizer, contribute $77 \%$ of the total nitrous oxide emission from Indian agricultural soils. ${ }^{5}$

Besides $\mathrm{N}_{2} \mathrm{O}$ emission, other oxidized and reduced $\mathrm{N}$ compounds $\left(\mathrm{NH}_{3}, \mathrm{NO}_{x}, \mathrm{NO}_{3}-\right)$ are also emitted from soils as result of use of $\mathrm{N}$ fertilizers which have short- and long-term, direct and indirect impacts on climate system. The emissions from agricultural soils is mainly dominated by $\mathrm{NH}_{3}$ (about 95\%) and $\mathrm{NO}_{x}$ (about 5\%) which results in formation of sulphur (S) containing aerosols having short term cooling impacts. These aerosols also regulate the oxidation capacity of the atmosphere by increasing the concentration hydroxyl radical $(\mathrm{OH})$, which acts as sink for methane $\left(\mathrm{CH}_{4}\right) \cdot{ }^{6}$ Therefore, the emissions of $\mathrm{NH}_{3}$ and $\mathrm{NO}_{x}$ have cooling effect on climate system through the process of aerosols formation and alteration of stratospheric ozone $\left(\mathrm{O}_{3}\right)$ and methane $\left(\mathrm{CH}_{4}\right)$ concentration.

Nitrogen application to agricultural soils affects not only the emission of nitrogenous compounds but it also affects the emission and uptake of carbon dioxide $\left(\mathrm{CO}_{2}\right)$ and methane $\left(\mathrm{CH}_{4}\right)$ from soils. Application of fertilizers in nitrogen limited agriculture system, usually increases productivity of agricultural crops, by increasing the $\mathrm{CO}_{2}$ fixation, ${ }^{7}$ and it enhanced carbon $(\mathrm{C})$ sequestration in agricultural soils due to increased crop residue production ${ }^{8}$ which have cooling impacts on climate system. Soils, particularly aerobic soils are the major sink for atmospheric $\mathrm{CH}_{4}$ and oxidation of $\mathrm{CH}_{4}$ by methane oxidizing bacteria (MOB) is the important methane removal process. However, use of fertilizers have inhibitory effects on MOB through ammonium ions $\left(\mathrm{NH}_{4}^{+}\right)^{9}$ and nitrate ions $\left(\mathrm{NO}_{3}-\right),{ }^{10}$ thereby decreasing the total $\mathrm{CH}_{4}$ uptake. ${ }^{11,12}$ results into warming impacts on climate system.

There are many studies in which the warming impacts of $\mathrm{N}_{2} \mathrm{O}$ emission alone as results of nitrogenous fertilizers use in agriculture is reported. If we consider only $\mathrm{N}_{2} \mathrm{O}$ emission there will be over

\author{
Volume 6 Issue 4 - 2017
}

\author{
Fagodiya RK,' Pathak $\mathrm{H},{ }^{2}$ Meena BL,' Meena \\ RK, ${ }^{3}$ Nagdev ${ }^{4}$ \\ 'Project Coordinating Unit, ICAR-Central Soil Salinity Research \\ Institute, India \\ ${ }^{2}$ CAR-National Rice Research Institute, India \\ ${ }^{3}$ Agronomy Section, ICAR-National Dairy Research Institute, \\ India \\ ${ }^{4}$ ICAR-National Bureau of Soil Survey and Land Use Planning, \\ RCD, India
}

\begin{abstract}
Correspondence: Fagodiya RK, Project Coordinating Unit, ICAR-Central Soil Salinity Research Institute, Karnal-I32 00I, India, Tel 0184-2209348, Email ram.iari4874@gmail.com
\end{abstract}

Received: February 16, 2017 | Published: February 21, 2017

estimation of the warming. To estimate the actual net warming caused by nitrogenous fertilizers use in agriculture the other impacts i.e. indirect $\mathrm{N}_{2} \mathrm{O}$ emission from $\mathrm{NO}_{3}$ - leaching (warming), aerosols formation as results of $\mathrm{NH}_{3}$ and $\mathrm{NO}_{x}$ emission (cooling), alteration of atmospheric $\mathrm{O}_{3}$ and $\mathrm{CH}_{4}$ (cooling), nitrogen induced carbon sequestration (cooling) and nitrogen induced $\mathrm{CH}_{4}$ uptake (warming) should we considered which will provide the new dimensions to the climate studies and helps in better management of nitrogenous fertilizers use in agricultural system.

\section{Acknowledgements}

None.

\section{Conflict of interest}

The author declares no conflict of interest.

\section{References}

1. Pathak H, Jain N, Bhatia A, et al. Improved nitrogen management: a key to climate change adaptation and mitigation. Indian Journal of Fertilisers. 2016;12(11):151-162.

2. Galloway JN, Aber JD, Erisman JW, et al. The nitrogen cascade. Bioscience. 2003;53(4):341-356.

3. IPCC. Climate Change 2014 Impacts, Adaptation, and Vulnerability. Part A: Global and Sectoral Aspects. Contribution of Working Group II to the Fifth Assessment Report of the Intergovernmental Panel on Climate Change. Cambridge University Press, Cambridge, USA: United Kingdom and New York; 2014.

4. Shine K, Fuglestvedt J, Hailemariam K, et al. Alternatives to the global warming potential for comparing climate impacts of emissions of greenhouse gases. Climate Change. 2005;68(3):281-302.

5. Pathak H, Bhatia A, Jain N, et al. Greenhouse gas emission and mitigation in Indian Agriculture - A review. In: ING Bulletins on Regional Assessment of Reactive Nitrogen. Bulletin No. 19, New Delhi: SCONING; 2010. p. 1-34. 
6. Isaksen ISA, Dalsoren SB. Getting a better estimate of an atmospheric radical. Science. 2011;331:38-39.

7. Hungate BA, Dukes JS, Shaw MR, et al. Nitrogen and climate change. Science. 2003;302:1512-1513.

8. Janssens IA, Dieleman W, Luyssaert S, et al. Reduction of forest soil respiration in response to nitrogen deposition. Nature Geoscience. 2010;3:315-322.

9. Wang Z, Ineson P. Methane oxidation in a temperate coniferous forest soil:effects of inorganic N. Soil Biology and Biochemistry. 2003;35(3):427-433.
10. Xu X, Inubushi K. Effects of $\mathrm{N}$ sources and methane concentrations on methane uptake potential of a typical coniferous forest and its adjacent. Biology and Fertility of Soils. 2004;40:215-221.

11. Steudler PA, Bowden RD, Melillo JM, et al. Influence of nitrogen fertilization on methane uptake in temperate forest soils. Nature.1989;341:314-315.

12. Leip A, Busto M, Corazza M, et al. Estimation of $\mathrm{N}_{2} \mathrm{O}$ fluxes at the regional scale:data, models, challenges. Current Opinion in Environmental Sustainability. 2011;3(5):328-338. 